\title{
An Analysis of Teacher's Strategies in Teaching Speaking
}

\author{
Aisyah Nurbaktiah \\ University of Bengkulu \\ aisyahnurbaktiah97@gmail.com \\ Syafrizal Sabaruddin \\ University of Bengkulu \\ syafrizal@unib.ac.id \\ Dedi Sofyan \\ University of Bengkulu \\ dedisofyan73@gmail.com \\ Corresponding email: aisyahnurbaktiah97@gmail.com
}

\begin{abstract}
The objectives of the research were to find out the strategies used by teachers in teaching speaking at SMAN 5 Kota Bengkulu and to describe how the teachers implement the strategies in the teaching process. This research was descriptive qualitative. The subjects were two English teachers who taught at tenth grade. The data were collected by using field notes and video documentation and were analyzed by using four procedures by Miles and Huberman namely data collection, data reduction, displaying data, and conclusion. The results showed that teacher 1 used seven strategies from twelve speaking strategies and teacher 2 used eight speaking strategies. The strategies used were Task Completion (50\%), Opinion Sharing (83.3\%), Information Transfer (16.6\%), Reasoning Gap (33.3\%), Questioning (100\%), Brainstorming (33.3\%), Scaffolding (100\%), and Drilling $(66.6 \%)$. Meanwhile, the other four speaking strategies were not used such as Information Gap, Jigsaw, Information Gathering, and Role Play. For the implementation, the teachers gave explanation and instruction to the students before applying the strategy. The teachers asked the students to work in pairs or groups which made them to communicate in English. In short, although the name of the strategy used by teachers was similar to each other, but the steps or ways carried out by them was different from one teaching to another. Furthermore, the teachers applied the strategies based on students' condition, need, and material in order to help students become more active in the process of teaching and learning.
\end{abstract}

Keywords: Teaching strategies, teaching speaking.

\section{Introduction}

Teaching strategy is one of the most important factors in the teaching and learning process. Today, Indonesian government published a new curriculum which is known as 2013 Curriculum. This curriculum uses a scientific approach. For applying this 
Jadila: Journal of Development and Innovation

in Language and Literature Education

Publisher: Yayasan Karinosseff Muda Indonesia
E-ISSN: 2723-6900

P-ISSN: 2745-9578

Volume. 1 Number 3, 2021

Page: 284- 301

approach, English teachers must have some competences and abilities. They must be able to develop the materials and to apply the appropriate strategies related to student's need and level, etc. This is supported by Harmer (2007), he claimed that English teachers should have competences to develop and adapt the materials based on the students' need and ability. Besides, they should be able to deliver the materials in a good way by applying some teaching strategies to support them in attracting students' attention and improving students' motivation to study English.

One of the most important skills in learning a language is speaking. Speaking skill is taught to the students in order to help them to be able to use English in real communication (Syafryadin, 2020; Syafryadin, et al. 2019; Syafryadin, et al. 2020; Syafryadin, 2020). However in learning English, there are still many students encountering some difficulties in this language. Ur (1996, p. 120) argued that good speaking classrooms are ones where learners talk a lot, there is participation, motivation is high and the language is appropriate at an acceptable level. However, based on the researcher's experience when she did an internship 2 for two months in one of SMAN in Kota Bengkulu, the researcher found that there were still many students who did not speak fluently, still low in vocabulary, and felt nervous and shy when they have to speak this language in front of the class. Furthermore, based on Dananjaya (2019), he analyzed students' speaking difficulties in SMAN 5 Kota Bengkulu, he found seven kinds of speaking difficulties faced by the students. Therefore, the researcher is interested to analyze this problem from the teacher's side. The researcher assumes that the teachers might not use appropriate strategies in their teaching activity.

To speak fluently, students should practice more and more in their English class. Depending on the 2013 curriculum which is implemented by using a Scientific Approach, the approach of this curriculum seems to have an objective to Communicative Language Teaching Approach on English language teaching speaking which enables students to communicate in the target language. Besides, there are some kinds of strategies which can support the process of teaching and learning English in this approach. According to Richards (2006, p. 18), there were some activities can be applied 
in a CLT classroom, they are information gap, jigsaw, task completion, information gathering, opinion sharing, information transfer, reasoning gap, and role play.

Furthermore, seven researchers have conducted related research. The first one is Anjaniputra (2013), the aims of the research were to find out the teacher's strategy in teaching speaking and to recognize the students' response toward strategies used by the teacher. He found that the strategies used by the teacher were cooperative activities, roleplay, creative tasks, and drilling. The students gave positive response towards the strategies. The second is Hia (2016), the aims of the research were to find out speaking strategies applied by the teacher and to know the students' response toward strategies used by the teacher. She found that three strategies were usually used by the teacher in teaching speaking. Such as discussion, communication games, and role play. The students give positive responses to the teacher's strategies.

The third is Nabilah (2019), the aims of the research were to find out teacher's strategies in teaching speaking and to explore the implementation of speaking techniques applied. She found that the teachers applied five techniques namely discussion, role play, brainstorming, reporting, and games. The fourth is Hakim (2017), the aim of the research was to provide a description of English teachers in Indonesia who are experienced in teaching speaking related to the challenges and strategies in teaching and learning process for students with introverted characteristics. He found that the teachers are advised to apply the discussion, role play, story telling, and interview.

The fifth is Widyaningsih, \& Robiasih (2018), the aims of the research were to describe the strategies used by the English teacher and to describe how the English teacher applies the strategies in teaching speaking. The result found that the teacher applied six strategies in science classes, while the teacher only applied four strategies in language classes. The implementation of those strategies was sufficiently executed. The sixth is Maulidar, dkk (2019), the aims of the research were to find out the teacher's strategy in teaching speaking and to know the students' response toward strategies used by the teacher. The results showed that the teachers used five strategies in teaching speaking namely: role play, drilling, games, describing picture, and also discussion 
group. The students' responses towards the strategies were positive. The seventh is Syafrizal, \& Rohmawati (2017), the aims of the research were to portray the teacher's strategies in teaching speaking and to recognize the students' response towards the strategies applied by the teacher. The results found that the strategies used were cooperative activities, role-play, creative tasks, and drilling. Students' response towards the strategies resulted in positive attitude.

This research is different from the seven previous studies. First, in this research, the researcher analyzed the way the teachers teach speaking based on strategies in communicative language teaching by Jack C. Richards and other speaking strategies appeared in the classes. Second from the research questions, some of the previous studies did not analyze about how the teacher's steps in applying the strategies found. Third, most of the previous studies only analyzed an English teacher so that the participant was limited. While in this research, the researcher analyzed two English teachers. The last one, the subject of this research was different from the previous studies. Because of those reasons, the researcher wants to observe the teacher's strategies in teaching speaking skill. To make sure that speaking skill exists in senior high school, the researcher looks the material from the syllabus. Through this research, the researcher focused on finding out the strategies used in teaching speaking at SMA 5 Kota Bengkulu and describing how the teachers implement the teaching speaking strategies at SMAN 5 Kota Bengkulu.

\section{Research Methodology}

This research used descriptive qualitative research design. As stated by Cresswell (2014:4), qualitative research is an approach for exploring and understanding the meaning individual or groups describes to a social or human problem. The participants of this research were two English teachers who taught at the first grade students in SMA 5 Kota Bengkulu. Further, teacher 1 has 14 years of teaching experience and has certified. While teacher 2 has 27 years of teaching experience and has certified too. The researcher implemented the research at SMAN 5 Kota Bengkulu. 
The researcher used three kinds of instruments. They were 1) Field Note, this instrument will contain a lot of contextual information that may frame the research in time, duration, and etc. (Phillippi, et al, 2017). A field note had been done in 3 meetings per each teacher on February $13^{\text {th }}-19^{\text {th }}$ 2020. 2) Video recording, the researcher recorded the process of teaching and learning an English lesson in video form. 3) Syllabus is used to make sure that the course of speaking skill is there in the senior high school.

In collecting the data, the researcher observed the process of teaching and learning situations by following steps. Such as 1) the researcher asked the teacher and told the teacher that the researcher will observe him/her in the process of teaching and learning. 2) The researcher saw the syllabus to make sure that speaking should be taught integrated in the teaching and learning activity. 3) The researcher used field notes in analyzing the teacher's strategies. 4) The researcher gave a sign and identified teacher strategy related to communicative language teaching.

Furthermore, the data were analyzed by using the procedures from Miles and Huberman (1994). The four procedures were as followed: 1) Data collection. In this step, the researcher collected the data from field notes and video documentation. 2) Data reduction. In this step, the researcher gained the data from field notes. Then, the researcher transcribed, selected, and focused on the essential data by referring to the research problems. 3) Displaying data. Data display was applied to see the whole of the data description. 4) Making conclusion is the process of drawing the content of the data collected in the form of statements.

The procedures of the research were conducted by the following steps. The procedures were as followed: 1) met the headmaster and the chief of academic and asked permission. 2) Met the teachers who will be observed. 3) The researcher followed the teacher classes. 4) The researcher observed two teachers by doing field notes. 5) The observation hold in three meetings each teacher and the duration was around 90 minutes. 6) After conducting the observation, the researcher give s sign for all speaking strategies applied. 7) Analyzing the data and making a conclusion. 
Jadila: Journal of Development and Innovation

E-ISSN: 2723-6900

in Language and Literature Education

P-ISSN: 2745-9578

Publisher: Yayasan Karinosseff Muda Indonesia

Volume. 1 Number 3, 2021

Page: 284- 301

\section{Result and Discussion}

The result and discussion of the research are in line with the objectives of the research namely to find out the strategies applied by the teachers and to describe how the teachers implement the strategy in the classes.

\section{Result of the Researcher's Field Notes of Strategies Applied by the Teachers in the} Classes.

In this part the researcher shows the strategies applied by the teachers in the classes.

Table 1: Strategies Used by the Teachers

\begin{tabular}{|c|c|c|c|c|c|c|c|c|c|}
\hline \multirow[t]{2}{*}{ No. } & \multirow[t]{2}{*}{ Strategies } & \multicolumn{3}{|c|}{$\begin{array}{l}\text { Teacher } 1 \\
\text { (Used) }\end{array}$} & \multicolumn{3}{|c|}{$\begin{array}{l}\text { Teacher } 2 \\
\text { (Used) }\end{array}$} & \multirow[t]{2}{*}{ Total } & \multirow{2}{*}{$\begin{array}{c}\text { Remarks } \\
\text { (Strategies } \\
\text { Applied) }\end{array}$} \\
\hline & & $\mathbf{1}$ & 2 & 3 & $\mathbf{1}$ & 2 & 3 & & \\
\hline 1 & Information Gap & - & - & - & - & - & - & 0 & Based on Richard \\
\hline 2 & Jigsaw & - & - & - & - & - & - & 0 & Based on Richard \\
\hline 3 & Task Completion & $\sqrt{ }$ & - & - & - & $\sqrt{ }$ & $\sqrt{ }$ & 3 & Based on Richard \\
\hline 4 & Information Gathering & - & - & - & - & - & - & 0 & Based on Richard \\
\hline 5 & Opinion Sharing & - & $\sqrt{ }$ & $\sqrt{ }$ & $\sqrt{ }$ & $\sqrt{ }$ & $\sqrt{ }$ & 5 & Based on Richard \\
\hline 6 & Information Transfer & - & - & - & $\sqrt{ }$ & - & - & 1 & Based on Richard \\
\hline 7 & Reasoning Gap & $\sqrt{ }$ & - & - & - & $\sqrt{ }$ & - & 2 & Based on Richard \\
\hline 8 & Role Play & - & - & - & - & - & - & 0 & Based on Richard \\
\hline 9 & Questioning & $\sqrt{ }$ & $\sqrt{ }$ & $\sqrt{ }$ & $\sqrt{ }$ & $\sqrt{ }$ & $\sqrt{ }$ & 6 & Appeared in class \\
\hline 10 & Brainstorming & - & - & $\sqrt{ }$ & - & - & $\sqrt{ }$ & 2 & Appeared in class \\
\hline 11 & Scaffolding & $\sqrt{ }$ & $\sqrt{ }$ & $\sqrt{ }$ & $\sqrt{ }$ & $\sqrt{ }$ & $\sqrt{ }$ & 6 & Appeared in class \\
\hline 12 & Drilling & $\sqrt{ }$ & $\sqrt{ }$ & - & $\sqrt{ }$ & $\sqrt{ }$ & - & 4 & Appeared in class \\
\hline
\end{tabular}

Based on the result of the table 1 above, there were twelve speaking strategies being observed in which eight speaking strategies were based on Richard (2006) and the other four speaking strategies were appeared in the class. There were two English teachers who being observed. Out of twelve speaking strategies only seven strategies applied by two teachers. The seven speaking strategies applied were task completion $(50 \%)$ was applied by teachers in three meetings. Opinion sharing (83.3\%) was applied by them in five meetings. Reasoning gap (33.3\%) was applied in two meetings. 
Questioning (100\%) was applied by teachers in every meeting of observations. Brainstorming (33.3\%) was applied in two meetings. Scaffolding (100\%) was applied in six meetings. The last drilling (66.6\%) was applied in four meetings. In addition, Information transfer $(16.6 \%)$ was only applied by teacher 2. Meanwhile, the other four speaking strategies were not seen such as information gap, jigsaw, information gathering, and role play.

Table 2: Seven Strategies Applied by the Teachers in the Class

\begin{tabular}{|c|l|c|l|c|}
\hline \multirow{2}{*}{ No. } & \multicolumn{2}{|c|}{ Teacher 1 } & \multicolumn{2}{c|}{ Teacher 2 } \\
\cline { 2 - 5 } & \multicolumn{1}{|c|}{ Strategies } & Used & \multicolumn{1}{c|}{ Strategies } & Used \\
\hline 1 & Task Completion & $\sqrt{ }$ & Task Completion & $\sqrt{ }$ \\
\hline 2 & Opinion Sharing & $\sqrt{ }$ & Opinion Sharing & $\sqrt{ }$ \\
\hline 3 & Information Transfer & - & Information Transfer & $\sqrt{ }$ \\
\hline 4 & Reasoning Gap & $\sqrt{ }$ & Reasoning Gap & $\sqrt{ }$ \\
\hline 5 & Questioning & $\sqrt{ }$ & Questioning & $\sqrt{ }$ \\
\hline 6 & Brainstorming & $\sqrt{ }$ & Brainstorming & $\sqrt{ }$ \\
\hline 7 & Scaffolding & $\sqrt{ }$ & Scaffolding & $\sqrt{ }$ \\
\hline 8 & Drilling & $\sqrt{ }$ & Drilling & $\sqrt{ }$ \\
\hline
\end{tabular}

This table 2 shows teacher 1 applied seven speaking strategies in teaching and learning process. While teacher 2 applied eight speaking strategies in his classes. Further, one strategy not applied by teacher 1 was information transfer.

\section{How Strategies Implemented by Teachers}

The first strategy was task completion activity. This strategy was used by the teacher to test the students about the material that has been learned or has been explained. Further, teacher 1 applied the strategy in one time of her meetings. While teacher 2 applied two times in his meetings. For example, in the first meeting of teacher 1, the steps used by the teacher were giving instruction to open the textbook, appointed students, asking students to read the paragraph, giving instruction to do the task, giving time, and appointed students and test them. Meanwhile in the second meeting of teacher 2, the steps 
Jadila: Journal of Development and Innovation

E-ISSN: 2723-6900

in Language and Literature Education

P-ISSN: 2745-9578

Publisher: Yayasan Karinosseff Muda Indonesia

Volume. 1 Number 3, 2021

Page: 284- 301

used were asked students to listen the text, teacher shows the text, giving instruction to re-arrange the paragraph of the text, discussed the answers together and test them. From the explanation before, it indicated that there are many variations in carried out the task completion. Even though the strategy used by teachers was similar but the steps carried out by them was different from one teaching to another.

The second strategy was opinion sharing. This strategy is used by the teachers to help the students to practice and to speak with the language. Teacher 1 applied the strategy in two times of her meetings and teacher 2 applied the strategies in three times. For example, In the first meeting of teacher 1, the steps used by the teacher were explained the material, giving instruction to open students' homework and discussed the answer together, asked the students to raise their hands, appointed students randomly, a student read the answer loudly, the teacher discussed the answer to other students and explained more about the answer, and continued to discuss the next questions. While in the first meeting of teacher 2, the teacher steps were teacher dictated the 8 questions to the students, instructed the students to share the answers to their seatmates, giving the example of how the way to share the answer to the partner, students answered the questions and share their answers, teacher inviting students' attention and discussed their advertisement. In short in applying the strategy, the steps used were same at the first step which giving explanation about the material, but it was differed for the next steps.

The third strategy was information transfer. This strategy is used by the teacher in helping the students to be more confident to present and to perform their speech in front of the class or in front of many people by using English. This strategy was only applied by teacher 2 . The steps applied by the teacher were explained the material, asked students to analyze the contents of the ads, instructed the students to discuss and gave time for the discussion, instructed the students to present their result in front of the class, students started to analyze the ad, asked students to raise their hands to present the result, and giving feedback for students' presentation. So in this strategy, teacher 2 instructed the students to perform the results of their analysis in front of the class. 
Jadila: Journal of Development and Innovation

in Language and Literature Education

Publisher: Yayasan Karinosseff Muda Indonesia
E-ISSN: 2723-6900

P-ISSN: 2745-9578

Volume. 1 Number 3, 2021

Page: 284- 301

The fourth strategy was reasoning gap. This strategy is used by the teachers to teach the students in deriving some new information from given information. Both teacher 1 and teacher 2 just applied the strategy in one time of their meetings. The steps used by teacher 1 were explained about the material, giving instruction to the students to open the textbook, giving task to the students and asked to discuss with students' seatmates, giving time to the students, asked students to read the sentences found, corrected students' pronunciation and gave feedback. While, teacher 2 applied some steps namely instructed the students to make questions from the paragraph, instructed the students to discuss with their seatmates and gave time for the discussion, asked the students to write the questions on the whiteboard, appointed students randomly, and discussed students' answers on the whiteboard together.

From the explanation above, the teachers applied different steps in their teaching strategy which teacher 1 started the steps by giving instruction to the students to open the textbook and instructed the students to find out the sentences of simple past tense in the text and discussed with their seatmates. While teacher 2 started the activity by giving explanation about the material to the students and instructed the students to make some question from the paragraph. So, it can be concluded that the teachers used the same strategy with different steps in applying the strategy. It can be happened because they applied the strategy based on the students' material and condition in that meeting.

The fifth strategy was questioning. This strategy is mostly used by the teachers in every meeting. In practicing the language, interaction is the most important factor in teaching speaking which in speaking the teachers hope the students actively practice their speaking. Further, teacher 1 and teacher 2 applied this strategy in every meeting. For example, in the first meeting of teacher 1, the teacher's steps were giving instruction to the students to open their textbook, instructed students to read and understand the text before coming to the class, asking the questions about the text that student have read, instructed students to answer the question by using English, continued to ask the next questions, and giving feedback for students' answer. While in the first meeting of teacher 2, the teacher applied some steps were as followed, the teacher asked about student 
condition, then, the teacher checked students' presence, teacher started the material, teacher asked some questions to the students about the material, the teacher instructed the students to raise their hands, students answered the questions and the teacher gave feedback for the students. In short, this strategy is very useful for the teachers to involve the students in practicing their English. Although, the students mostly answered the teachers' questions briefly.

The sixth strategy was scaffolding. This strategy is used by the teachers in inviting students' attention, instructing students, modelling, and reinforcing them which helped the students to know how to do something. The teachers applied scaffolding strategy in every meeting. For example in the first meeting of teacher 1, the steps applied by the teacher were giving instruction to open the text, asked students to read the text, giving instruction to students to listen their friends, inviting students' attention, and giving feedback for student who has read the text. For the last meeting, the steps used were explained about the material, instructed the students to open the text and answer the questions, and asked students to discuss the answers together. Further, in the first meeting of teacher 2, the teacher applied some steps namely reviewed the material, asking questions about the material, instructed the students to raise their hands. Furthermore, it can be happened because this strategy is the teachers' expressions to interact with the students.

The seventh strategy was brainstorming, this strategy is used by the teachers to lead the students about the new material in the class. The teachers only applied this strategy in one time of their meetings. Teacher 1 applied some steps in her meeting. They were explained about the material, giving instruction to open and read the text, asking questions about the text, lead students to guess the material from the explanation, students answered together, and continued to explain the material. While, teacher 2 informed the students about the new material and asked some questions to lead the students to understand more about the material.

The last strategy was drilling, this strategy is focused on a form of the language and it is used by the teacher in correcting students' pronunciation. In this strategy, teacher 
1 applied the strategy in two times of her meetings and teacher 2 applied the strategy in two times too. For the example, in the first meeting of teacher 1, the steps applied were giving instruction to open the text, asking the students to read the paragraph, inviting students' attention, instructed the students to pronounce some words, corrected students' pronunciation directly, and giving feedback to the students. While in the first meeting of teacher 2, the teacher applied some steps namely explained about the material, giving instruction to the students to analyze, giving example and time, asking students to perform the result, and giving feedback to the student. From the steps applied by the teachers before, it shows that the teachers applied the strategy in the different steps but have one aim that for corrected students' pronunciation. So in short, the teacher can be varied the activity of one strategy in the teaching and learning process even though the name of the strategy was similar.

\section{Discussion}

\section{The Strategies Used by the Teachers in Teaching Speaking}

In this research, it was found that teacher 1 used seven speaking strategies and teacher 2 used eight speaking strategies in the classes. It might happen because the teachers applied those strategies based on the students' level, students' condition and material in the class. It is supported by Anjaniputra (2013), he suggested that the teacher used strategies of teaching speaking in accordance with students' characteristic and level of proficiency, and the teacher also provided material that involved students to be more active by using various available strategies in teaching speaking.

Furthermore, the teachers did not apply the four strategies from twelve speaking strategies. It might happen because those strategies did not relevant to the material in the meetings. Besides, the teachers also might apply the speaking strategies that were appropriated with the students' ability in English. It is supported by Nabilah (2019), she stated that the strategies applied by the teacher were based on the material that will be taught by the teacher and the students' English background.

As mentioned in the result, the teachers applied drilling in their teaching activity. This finding is in line with the result of the previous study by Anjaniputra (2013) which 
the teacher applied drilling as speaking strategy in the teaching process. The next strategy found in this research was brainstorming. This strategy was applied by the two English teachers. This finding is in line with Nabilah (2019), she found that the teachers applied brainstorming as a speaking technique in her research.

Then, the next strategy that was applied by the teacher was opinion sharing activity. In this strategy, the teachers asked the students to share idea about things and find out a solution which can be done by working in pair or group. It is supported by Richard (2006), he said students can give their opinions to others and compare their or other values, opinions, or beliefs in this activity. This result is in line with the previous study by Hia (2016), she found that the teacher applied discussion as a speaking strategy. Moreover, other six strategies were applied by the teachers did not find in the previous studies. Further, role play was found by the some previous studies but it is contrasted with this research which the teachers did not apply this strategy in the class.

Furthermore, both of the English teachers did not apply all the strategies observed in this research. However, even though the teachers did not apply all the strategies based on Richard (2006), it does not mean that applying all the strategies are better than applying some of them. The effectiveness of applying the strategies is more important than the number of strategies applied. Thus, from the finding, it can be concluded that even though the strategies applied by the teachers were similar to each other but the teachers varied his or her steps in applying the strategies in the teaching process. In short, the variation of applying the strategy is the most important issue. This is supported by previous studies which the students gave positive response toward strategies applied by the teachers, even though the strategies applied by the teachers in the previous studies were fewer than the strategies found in this research.

\section{The Implementation of Strategies Used by Teachers}

In the implementation of teaching speaking strategy in SMAN 5 Kota Bengkulu, the teachers explained and gave the instruction to the students before applying the strategy which were supposed to give clear and understandable instruction, so that the students knew what they had to do in the process of learning. It is in line with Thornbury 
Jadila: Journal of Development and Innovation

E-ISSN: 2723-6900

in Language and Literature Education

P-ISSN: 2745-9578

Publisher: Yayasan Karinosseff Muda Indonesia

Volume. 1 Number 3, 2021

Page: 284- 301

(2005), he stated that language productivity can be increased by making sure that speaking activity has a clear out come. However, there are also some speaking strategies which the teachers should not tell the explanation and instruction before applying the strategy, for example scaffolding strategy.

The first is task completion. In this strategy, the teacher gave the task that should have been completed by the students. This strategy was applied by the teachers in enjoyable activity so that the students became happy in doing the task. It is supported by Richard (2006), he stated that task completion activity means the teacher can applying puzzles, games, map-reading, and other kinds of classroom tasks in which the focus is on using one's language resources to finish a task.

The second is opinion sharing. In this activity, student could improve their speaking skill by discussing and sharing about something. It is supported by Richard (2006), he stated that this strategy is a useful activity which students can share their opinions to others and compare it.

The third is information transfer. This strategy is one of important activity in building students' confidence in speaking. In this activity, the students were required to take the information or analyze something which was presented in one form and made conclusion or result to present it in the different form.

The fourth is reasoning gap. This strategy is a student's activity to derive new information from given information. For example from strategy applied by teacher, the material on that day was recount text. Then teacher asked the students to read the text and asked them to find out the sentences of simple past tense and report their result in front of the class.

The fifth is questioning strategy. This strategy is the teacher way to check the students' understanding about what they have been taught and to help students in practicing the language in classroom interaction. This is supported by Ma, X (2008) who stated raising questions effectively is a major strategy of a teacher who guides his or her students to think actively, developing students' ability of analysis and creation, and an important way to exchange ideas between teacher and students. In this activity, the 
teachers gave questions to the students at the time in order to build an interaction between them. It is supported by Hughes (2003: 113) he stated that the objective of teaching spoken language is the development of the ability of the learners to interact successfully in that language, so that it involves comprehension as well as production.

Sixth, scaffolding strategy is the teaching speaking strategy which was used by the teachers to interact and give example to students in the classroom. It is supported by Van Der Stuyf (2002) who stated Scaffolding as a teaching strategy originated from Lev Vygotsky's sociocultural theory and his concept of the zone of proximal development (ZPDF). Furthermore, Gibbons (2014) stated that scaffolding is the temporary assistance which a teacher helps students to know how to do something so that the students will be able to complete similar task by themselves. Some activities that can be applied such as inviting students' participation, modelling the students, reinforcing the students, and giving instruction to them.

Seventh, brainstorming was used by the teachers to lead the students to produce an idea in limited time. It depends on the context, either individual or group brainstorming. The teacher brainstormed the students to find out the new material that will be learned in the meeting.

The eighth is drilling. This activity used by the teacher when the students read the text or answering the question. The teachers listened to the students and corrected students' pronunciation directly. This strategy help students improve in pronouncing the words. As stated by Thornbury (2005) drilling is a strategy to improve pronunciation.

Furthermore, from twelve speaking strategies observed, the teachers did not apply four speaking strategies. The other four strategies not applied by the teachers were information gap, jigsaw, information gathering, and role play.

\section{Conclusion and Suggestion}

\section{Conclusion}

After doing the research, it can be concluded that teacher 1 applied seven strategies from twelve speaking strategies. While, teacher 2 applied eight speaking 
strategies in the class. This research is similar with the previous studies which the teacher applied the strategies based on the students' condition, need, and material. However, the frequency of strategies applied was quite different with the previous studies which the first previous study only found four strategies applied by a teacher, the second previous study found three strategies applied by the teacher in her research, and the last previous study found five techniques applied by the teachers.

Furthermore, even though the teachers did not apply all the speaking strategies based on Richard (2006), it does not mean that the number of strategies applied is more important than the effectiveness of applying the strategies. So, it can be concluded that even though the teachers only applied several strategies or not accomplished all the strategies, it does not mean that the teachers' strategies are less communicative. However, the effectiveness of applying the strategies is very important which variation is the most important issue. In addition, the teachers applied the different steps in applying a strategy.

\section{Suggestion}

For the English teacher, an English teacher should try and explore other communicative strategies to support the teaching and learning process become more communicative which can give a chance for students to practice among them and improve their fluency. Furthermore, the teacher can make an activity which can improve students' interest and motivation in learning English by asking students to perform English Drama as an important task to get a point. Besides, the teacher can make a fun and enjoyable classroom which supports the students to be confident and fluent in speaking because the purpose of learning a language is to be able to communicate meaningfully.

For the further researcher, the further researcher has to observe at least six meetings for each teacher to find out more strategies applied by the teachers. Then, the further researcher should determine the time of observation which the material is appropriate with teaching speaking. The last one is for the research question, the further researcher can add how students respond toward the strategies which will be applied by the teacher in order to know the strategies applied is effective or not for the students. 


\section{References}

Anjaniputra, A. G. (2013). Teacher's strategies in teaching speaking to students at secondary level. Journal of English and Education, 1(2), 1-8.

Brown, H. D (2004). Language assessment: principles and classroom practices. New York: Pearson Education.

Creswell, J. W. (2014). Research design: qualitative, quantitative, and mixed method approaches. 4th ed. California: Sage Publication.

Dananjaya, T. (2019). An analysis of students' speaking difficulties of exposition text at the eleventh grade in SMAN 5 Bengkulu city (Undergraduate Thesis), Bengkulu University, Bengkulu.

Gibbons, P. (2002). Scaffolding language, scaffolding learning. Portsmouth, NH: Heinemann.

Hakim, M. A. R. (2017). Teachers' strategies in teaching speaking lessons on introvert students in madrasah aliyah (MA) Ja-alHaq Bengkulu. Madania: Jurnal Kajian Keislaman, 21(1), 23-30.

Harmer, J. (2007). The practice of English language teaching. Longman.

Hia, I. J. F. (2016). The Teacher's Strategies in Teaching Speaking Ability (A Study on the First Grade Students of SMAN 1 Ngamprah Academic Year 2016-2017). Bandung: Universitas Pasundan press. Retrieved from http://repository.unpas.ac.id/13154/

Hughes, A. (2003). Testing for language teachers. Cambridge University Press

Kayi, H. (2012). Teaching speaking: Activities to promote speaking in a second language. Новейшие научные достижения, 12(2012). Retrieved from http://iteslj.org/Techniques/Kayi-TeachingSpeaking.html

Kemendikbud. (2013). Kurikulum 2013 Kompetensi Dasar Sekolah Menengah Atas (SMA)/ Madrasah Aliyah (MA).

Ma, X. (2008). The skills of teacher's questioning in English classes. International Education Studies. 1(4), 92-100. 
Maulidar, K., Gani, S. A., \& Samad, I. A. (2019). Teacher's Strategies in Teaching Speaking for Cadets. English Education Journal, 10(1), 80-94. Retrieved from http://e-repository.unsyiah.ac.id/EEJ/article/view/13258

Miles, B. M., \& Huberman, M. A. (1994). Qualitative data analysis. USA: Sage Publications.

Nabilah, R (2019). Exploring teachers' techniques in teaching speaking at MAN 2 Kepahiang (Undergraduate Thesis), Bengkulu University, Bengkulu.

Phillippi, J., \& Lauderdale, J. (2018). A guide to field notes for qualitative research: context and conversation. Qualitative Health Research, 28(3), 381-388.

Syafrizal, S., \& Rohmawati, C. (2017). Teacher's speaking strategies at vocational high school. Journal of English Language Studies, 2(1). 3.

Richards, J. C. (2006). Communicative language teaching today. New York: Cambridge University Press.

Syafryadin, S., Martina, F., \& Salniwati, S. (2020). Compensation strategies in speaking activities for non-English department students: poor and competent speakers. JEES (Journal of English Educators Society), 5(2), 109-116.

Syafryadin, S. (2020). Students' strategies in learning speaking: Experience of Two Indonesian Schools. Vision: Journal for Language and Foreign Language Learning, 9(1), 33-46.

Syafryadin, H., \& Salniwati, A. R. A. P. (2019). Digital storytelling implementation for enhancing students' speaking ability in various text genres. International Journal of Recent Technology and Engineering (IJRTE). 8(4), 3147-3151.

Syafryadin, S. (2020). The Effect of Talking Chips Technique Toward the Improvement of Students' Speaking Achievement at one of the Senior High Schools in Bandung. Linguists: Journal Of Linguistics and Language Teaching, 6(2), 1-13.

Thornbury, S. (2005). How to teach speaking. England: Pearson Educational Limited.

Trialoka, V. S., Puspita, H., \& Sabarudin, S. (2017). English learners' strategies in learning speaking skill (A study of undergraduate student of English education study program at Universitas Bengkulu in 2016/2017 academic year. Journal of English Education and Teaching, 1(1), 9-20. 
Jadila: Journal of Development and Innovation

E-ISSN: 2723-6900

in Language and Literature Education

P-ISSN: 2745-9578

Publisher: Yayasan Karinosseff Muda Indonesia

Volume. 1 Number 3, 2021

Page: 284- 301

Ur, P. (1996). A course in language teaching: practice and theory. New York: Cambridge University Press.

Van Der Stuyf, R. R. (2002). Scaffolding as a teaching strategy. Adolescent learning and development, 52(3), 5-18.

Widyaningsih, D., \& Robiasih, R. H. (2018). Teacher's strategies in teaching speaking skill for eleventh grade students at SMA Bopkri 2 Yogyakarta. JELLT (Journal of English Language and Language Teaching), 2(1), 46-58. 